\title{
Immunocytochemical study of 18 tumours causing ectopic Cushing's syndrome
}

\author{
P J COATES, ${ }^{*}$ I DONIACH, ${ }^{*}$ T A HOWLETT, $\dagger$ LESLEY H REES, $\ddagger$ G M BESSER $\dagger$ \\ From the Departments of ${ }^{*}$ Histopathology, $\dagger$ Endocrinology, and $\ddagger$ Chemical Endocrinology, St Bartholomew's \\ Hospital, London
}

SUMMARY Eighteen cases of Cushing's syndrome caused by ectopic production of peptide hormones were investigated by histological and immunocytochemical methods and the findings correlated with clinical and biochemical observations. Immunocytochemistry showed immunoreactive adrenocorticotrophic hormone (ACTH) or peptides derived from the ACTH precursor (pro-opiomelanocortin (POMC)), or both, in a total of 10 cases: five of these also contained immunoreactive- $\alpha$-melanocyte stimulating hormone, indicating more extensive translational processing of POMC than normally occurs in healthy corticotrophs of the anterior pituitary; in two further cases peptides capable of stimulating ACTH release from the anterior pituitary were present. In the remaining six cases immunocytochemistry failed to show the presence of ACTH, other POMC derived peptides, or peptides with ACTH releasing properties. These findings correlate well with the histological and clinical observations, in that the six tumours had been clinically overt, caused rapid death, and histologically seemed to be highly malignant. In contrast, the 12 other tumours were occult to radiological examination, patients had a much improved survival rate, and histologically the tumours seemed to be less aggressive. All but one of the tumours in this series showed a degree of neuroendocrine differentiation, indicated by the presence of neuron specific enolase.

These results suggest that one feature of highly malignant tumours, which cause an ectopic endocrine syndrome, is a high secretion of peptide hormones, leaving amounts that are too small to be shown by immunocytochemistry.

Howlett et al recently reviewed all the cases of Cushing's syndrome caused by hypersecretion of adrenocorticotrophic hormone (ACTH) investigated in the department of endocrinology at this hospital between 1969 and $1985 .{ }^{1}$ Of 71 patients, 16 cases resulted from secretion of ACTH from an ectopic site. They were able to divide patients into two groups on the basis of clinical observations at the time of presentation. Group 1 patients $(n=6)$ had obvious signs of an underlying tumour, while those in group 2 $(n=10)$ had tumours that were occult to radiological examination, and extensive investigation was required for their localisation. ${ }^{1}$ We now report the histological and immunocytochemical features of these 16 tumours and of two additional cases in which the tumours were also clinically occult. We were particularly interested to note any correlation between the histological tumour type, the range of peptides that could be shown in tumour cells, and the clinical and biochemical findings.

Immunocytochemistry was used primarily to indicate the presence of ACTH in tumour cells. As this hormone is produced as a large precursor molecule, termed pro-opiomelanocortin (POMC) ${ }^{2}$ we also used antibodies raised against the $\mathrm{N}$ - and $\mathrm{C}$-terminal portions of POMC. The precursor may also undergo differential post translational processing in different corticotroph cell types in the pituitary, with the formation of different final peptide products. $^{2}$ To investigate the extent of POMC processing in our tumours we used the presence of immunoreactive $\alpha$-melanocyte stimulating hormone, a 13 amino acid peptide typically produced from ACTH in cells of the pars intermedia by proteolytic cleavage and further processing. ${ }^{2}$ An antiserum recognising human corticotrophin releasing factor (CRF-41) was also used, as the ectopic secretion of this peptide has recently been confirmed to be a cause of Cushing's syndrome. ${ }^{3}$ 
Table 1 Details of antisera used

\begin{tabular}{|c|c|c|c|}
\hline Antisera to & Source & Dilution & Control tissue \\
\hline Neuron specific enolase & Dako Ltd, UK & $1 / 1000$ & Lung carcinoid \\
\hline N-terminal POMC & Dr S Jackson* & $1 / 1000$ & Pituitary \\
\hline C-terminal POMC & Dr S Jackson* & $1 / 200$ & Pituitary \\
\hline ACTH $1-24$ & Dr A Hale ** & $1 / 400$ & Pituitary \\
\hline$x$-melanocyte stimulating hormone & Dr S Ratter** & $1 / 600$ & Fetal pituitary \\
\hline CRF-4I & Dr E Linton* & $1 / 400$ & Pituitary stalk \\
\hline Bombesin & Dr J Price** & $1 / 400$ & Lung carcinoid \\
\hline Calcitonin & Immuno Nuclear Corporation, USA & $1 / 100$ & Thyroid \\
\hline Somatostatin & Guildhay Antisera, UK & $1 / 600$ & Pancreas \\
\hline Human chorionic gonadotrophin & Dako Ltd, UK & $1 / 500$ & Placenta \\
\hline$x$-human chorionic gonadotrophin & Dr C McLean* & $1 / 1200$ & Pituitary \\
\hline$\hat{\beta}$-human chorionic gonadotrophin & Orthodiagnostics, USA & $1 / 800$ & Placenta \\
\hline
\end{tabular}

*Pituitary hormone laboratory, St Bartholomew's Hospital.

** Department of Chemical Endocrinology, St Bartholomew's Hospital.

Antisera to various other peptide hormones were used to search for possible tumour markers, as well as providing information concerning the peptides that may be produced in association with ACTH by certain tumour types. Finally, we used an antiserum to neuron specific enolase, a marker for cells derived from the diffuse neuroendocrine system $^{4}$ to investigate the proportion of tumours showing neuroendocrine characteristics.

\section{Material and methods}

Tissues from 17 cases were removed during surgery or at necropsies performed on patients diagnosed and managed in our unit. Sixteen patients had suffered from ectopic ACTH production, ${ }^{1}$ while the other patient had been previously reported as a case of ectopic bombesin production causing excessive pitu- itary ACTH secretion. ${ }^{5}$ Material from one further patient had been referred for immunostaining. In all cases tissues were fixed in $10 \%$ formol saline before routine processing to paraffin wax. Blocks of tumour in 16 cases were recut and freshly stained by an indirect immunoperoxidase technique, using the primary antisera detailed in table 1 . After blocking endogenous peroxidase activity with $0.35 \% \mathrm{H}_{2} \mathrm{O}_{2}$ in methanol sections were incubated with appropriately diluted primary antisera for 16 hours at $4^{\circ} \mathrm{C}$. Affinity purified, peroxidase labelled, donkey antirabbit IgG (Guildhay Antisera, Guildford, United Kingdom $\mathbb{B}$ was applied diluted $1 / 300$ for 30 minutes at room tem perature and immunoreactive sites shown by polyes merisation of diaminobenzidine tetrahydrochloride (DAB) (Sigma Chemicals, Dorset, United Kingdom).

Immunostaining controls included staining of known positive tissues (table 1) and replacement of

Table 2 Patient details and histological classification

\begin{tabular}{|c|c|c|c|c|}
\hline Case No & Age and sex & $\begin{array}{l}\text { *Plasma ACTH } \\
(\text { ng } / l)\end{array}$ & Histological diagnosis & $\begin{array}{l}\text { Survival following } \\
\text { presentation } \\
\text { (in years and months) }\end{array}$ \\
\hline \multicolumn{5}{|c|}{ Smoll cell carcingma flung } \\
\hline 1 & $67 \mathrm{M}$ & 1502 & Small cell carcinoma of lung & Dead 7 months \\
\hline 2 & $52 \mathrm{~F}$ & 662 & Small cell carcinoma of lung & Dead 6 months \\
\hline 3 & $64 \mathrm{M}$ & 389 & Small cell carcinoma of lung & Dead 6 months \\
\hline 4 & $33 \mathrm{~F}$ & 2340 & Undifferentiated carcinoma of colon & Dead 1 month \\
\hline 5 & $37 \mathrm{M}$ & 907 & Malignant pancreatic endocrine tumour & Dead 2 months \\
\hline 6 & $68 \mathrm{~F}$ & 1459 & Atypical carcinoid of gall bladder & Dead 1 month \\
\hline \multicolumn{5}{|l|}{ Group 2} \\
\hline 7 & $42 \mathrm{M}$ & 165 & Carcinoid of lung & Alive $161 / 2$ years \\
\hline 8 & $72 \mathrm{M}$ & 92 & Carcinoid of lung & Dead $3 \frac{1}{2}$ years \\
\hline 9 & $37 \mathrm{~F}$ & 141 & Carcinoid of lung & Alive $61 / 2$ years \\
\hline 10 & $26 \mathrm{~F}$ & 69 & Carcinoid of lung & Alive $51 / 2$ years \\
\hline 11 & $49 \mathrm{~F}$ & 244 & Carcinoid of lung & Alive $1 \frac{1}{2}$ years \\
\hline 12 & $54 \mathrm{~F}$ & 121 & Carcinoid of lung & Dead $41 / 2$ years \\
\hline 13 & $36 \mathrm{M}$ & 230 & Carcinoid of thymus & Dead $101 / 2$ years \\
\hline 14 & $42 \mathrm{~F}$ & 82 & Carcinoid of thymus & Alive $81 / 2$ years \\
\hline 15 & $34 \mathrm{M}$ & 134 & Pancreatic endocrine tumour & Alive 8 years \\
\hline 16 & $55 \mathrm{M}$ & 123 & Phaeochromocytoma & Alive 10 years \\
\hline 17 & $61 \mathrm{M}$ & 399 & Phaeochromocytoma & Alive 6 months \\
\hline 18 & $43 \mathrm{M}$ & 185 & Medullary carcinoma of thyroid & Alive $21 / 2$ years \\
\hline
\end{tabular}

*Data for case nos 1-16 are taken from reference ${ }^{1}$ and represent the mean of six samples. 
primary antisera by serum from a non-immunised rabbit. The staining patterns of each antiserum were observed both in normal and neoplastic tissues and seemed to be specific for the given antigen. The peptide hormone antisera had been characterised for use in radioimmunoassay and in many instances tested by liquid phase absorption with the synthetic peptide. In two cases no further material was available: table 2 includes the original findings.

Immunostained sections were assessed independently by two observers (PJC and ID) and results were partially quantified on a scale of 0 to 3 on the basis of the percentage of cells staining positively.

Patients were divided into the same two groups mentioned previously, purely on the basis of clinical observations at the time of presentation.

\section{Results}

\section{HISTOLOGY}

Table 2 gives the details of clinical and histological observations. Group 1 tumours consisted of three small cell carcinomas of the lung, one atypical carcinoid of the gall bladder, one pancreatic endocrine tumour, and one undifferentiated carcinoma of the colon. Each of these tumours was highly malignant and all had metastasised. All patients died within eight months of presentation. More slow growing, relatively benign carcinoid tumours predominated in group 2 patients, comprising six lung carcinoids and two thymic carcinoids. One pancreatic endocrine tumour, one medullary carcinoma of the thyroid, and two phaeochromocytomas were also present. Histologically, these tumours seemed to be far less agressive than those of group 1. Three patients in group 2 have subsequently died, but only after a period of time from between $31 / 2$ and $101 / 2$ years following diagnosis.

\section{IMMUNOCYTOCHEMISTRY}

Table 3 gives the full results of our immunocytochemical investigation. Antisera recognising the $\mathrm{N}$ - and C-terminal portions of the ACTH precursor were positive in 10 cases, all belonging to group 2 . Immunoreactive ACTH was itself detectable in seven of these cases and immunoreactive- $\alpha$-melanocyte stimulating hormone in five cases. Of the remaining two cases in group 2, immunoreactive corticotrophin releasing factor (CRF-41) was shown in case 17 and the bombesin like peptide seen in case 18 had been shown to have accounted for this patient's Cushing's syndrome. ${ }^{5}$ No evidence for the causative agent of the observed Cushing's syndrome could be found in any of the tumours of group 1.

Other regulatory peptides were also more commonly seen in group 2 tumours than in those of group
1. Thus immunoreactive bombesin was seen in a total of seven cases, all belonging to group 2. Immunoreactive calcitonin was found in five group 2 tumours but in none of the tumours of group 1. Immunoreactive human chorionic gonadotrophin was seen in a total of seven cases, six belonging to group 2. Each of the six group 2 tumours contained only the $\alpha$ subunit, while in the single positive group 1 tumour both $\alpha$ and $\beta$ subunits were detected. Somatostatin was present in one case from each group. Neuron specific enolase immunostaining was positive in all but the one case of an undifferentiated carcinoma of the colon included in group 1.

\section{Discussion}

The association between Cushing's syndrome and tumours of "non-endocrine" organs dates back to $1928 .^{6}$ Since then the presence and secretion of ACTH by such tumours has repeatedly been shown. ${ }^{78} \mathrm{~A}$ wide variety of tumours may cause Cushing's syndrome, most of these tumours being derived from cells of the diffuse neuroendocrine system (formerly APUD), ${ }^{910}$ so that the term "nonendocrine" is no longer considered to be appropriate for most tumours. The term "ectopic" was introduced to describe the production by neoplastic tissues of hormones that are not produced normally by the tissue of origin. ${ }^{11}$ It must always be borne in mind, however, that a wide variety of tissues synthesise peptide hormones, including ACTH, under normal conditions, ${ }^{12}$ so that hormone elaboration by a tumour may not be "ectopic" in the strictest sense of the word.

"Ectopic" hormone production is said to account for between 12 and $25 \%$ of cases of Cushing's syndrome, and small cell carcinomas are the most commonly recognised tumour. ${ }^{13}$ These tumours produce symptoms quite unlike those of classical Cushing's syndrome, caused mainly by the effects of a rapidly growing highly malignant tumour. The presence of a relatively small, more benign tumour secreting ACTH, however, typically a lung carcinoid, will produce clinical features that mimic pituitary ACTH dependent Cushing's disease more closely. ${ }^{14}$ In this series such tumours accounted for 10 of 18 cases, with two further occult tumours secreting peptides with ACTH releasing activity, while only three cases were small cell carcinomas of the lung.

These findings contrast sharply with those of previous reports, ${ }^{8-1013}$ and are probably attributable to the development of more thorough and precise investigative procedures ${ }^{1}$-and possibly the selective influence of a specialised unit towards the more difficult differential diagnosis of Cushing's syndrome. 
Table 3 Results of immunocytochemical investigations

\begin{tabular}{|c|c|c|c|}
\hline \multirow[b]{2}{*}{ Case No } & \multirow[b]{2}{*}{ Tissue studied } & \multicolumn{2}{|l|}{ Antibodies } \\
\hline & & $\begin{array}{l}\text { Neuron specific } \\
\text { enolase }\end{array}$ & $N-P O M C$ \\
\hline Group 1 & $\begin{array}{l}\text { Primary tumour } \\
\text { Liver metastasis }\end{array}$ & $\begin{array}{l}2 \\
2\end{array}$ & $\begin{array}{l}0 \\
0\end{array}$ \\
\hline 2 & Lymph node metastasis & 2 & 0 \\
\hline 3 & $\begin{array}{l}\text { Primary tumour } \\
\text { Lymph node metastasis }\end{array}$ & $\begin{array}{l}2 \\
2\end{array}$ & $\begin{array}{l}0 \\
0\end{array}$ \\
\hline 4 & Primary tumour & 0 & 0 \\
\hline 5 & Liver metastasis & 3 & 0 \\
\hline 6 & $\begin{array}{l}\text { Primary tumour } \\
\text { Liver metastasis }\end{array}$ & $\begin{array}{l}3 \\
3\end{array}$ & $\begin{array}{l}0 \\
0\end{array}$ \\
\hline$\underset{7}{\text { Group } 2}$ & Primary tumour & 3 & 1 \\
\hline 8 & Liver metastasis & 3 & 1 \\
\hline 9 & Primary tumour & 1 & 2 \\
\hline 10 & Primary tumour & 2 & 1 \\
\hline 11 & Primary tumour & 3 & 3 \\
\hline 12 & Lymph node metastasis & & \\
\hline 13 & $\begin{array}{l}\text { Primary tumour } \\
\text { Primary tumour (recurrence) }\end{array}$ & $\begin{array}{l}3 \\
2\end{array}$ & $\begin{array}{l}2 \\
2\end{array}$ \\
\hline 14 & Primary tumour & & \\
\hline 15 & Primary tumour & 3 & 1 \\
\hline 16 & Primary tumour & 3 & 1 \\
\hline 17 & Primary tumour & 3 & $\mathbf{0}$ \\
\hline 18 & Lymph node metastasis & 3 & 0 \\
\hline
\end{tabular}

Staining: $0=$ negative; 1 = very few cells positive; $2=$ many cells positive, but less than $50 \% ; 3=$ greater than $50 \%$ of cells positive.

Immunocytochemical investigation of our cases pinpointed several interesting aspects. First, there is the one case that was negative when immunostained for neuron specific enolase. This case was that of an undifferentiated carcinoma of the colon and seems to have been genuinely responsible for the observed clinical syndrome, as no other cause could be found at necropsy. Moreover, the rapid onset of the patient's illness and the exaggeratedly high concentrations of plasma ACTH $(2340 \mathrm{ng} / \mathrm{l})$ found by radioimmunoassay are not in keeping with a smaller, slow growing tumour, which might possibly have escaped detection, nor with pituitary dependent Cushing's disease. The association between Cushing's syndrome and tumours that do not display neuroendocrine characteristics seems to be rare but genuine and has been reported for carcinoma of the colon. ${ }^{1516}$ In spite of this neuron specific enolase immunostaining was still the most reliable diagnostic aid in this study.

We were able to show the presence of POMC derived peptides in a total of 10 cases, although ACTH itself was found in only seven of these. This lack of immunoreactive ACTH in cases in which other POMC derived peptides were present could theoretically, be due to selective secretion of ACTH by tumour cells. Such a hypothesis is unlikely, as it has been shown that POMC peptides are secreted concomitantly by both pituitary adenomas and ectopic ACTH producing tumours. ${ }^{17} \mathrm{~A}$ more plausible explanation is the presence of larger molecular weight precursor forms, which are not immunoreactive to our particular anti-ACTH serum, caused by different structural arrangements of the peptide sequences. Similar conclusions were drawn from an immunocytochemical study of the reactivities seen in glucagonomas using antisera to glucagon and other portions of its precursor. ${ }^{18}$ The presence of immunoreactive $\alpha$-melanocyte stimulating hormone in five cases is indicative of more extensive processing of POMC than normally occurs in normal pituitary corticotrophs and which is seen in corticotroph adenoma causing Cushing's disease. ${ }^{19}$

Immunoreactive CRF-41 was found in one case of $\mathrm{N}$ phaechromocytoma, and presumably accounts for this patient's Cushing's syndrome. The structure of CRF-41 has only recently been determined, ${ }^{20}$ so that the true incidence of ectopic CRF-41 secretion is still unknown. There are two previous reports of immunocytochemically verified CRF-41 production, one by a prostatic carcinoma, ${ }^{3}$ the other by a medullary 


\begin{tabular}{|c|c|c|c|c|c|c|c|c|}
\hline$C-P O M C$ & $\alpha-M S H$ & $C R F$ & Bombesin & Somatostatin & Calcitonin & $\begin{array}{l}\text { Human } \\
\text { chorionic } \\
\text { gonadotrophin }\end{array}$ & $\begin{array}{l}\alpha \text {-Human } \\
\text { chorionic } \\
\text { gonadotrophin }\end{array}$ & $\begin{array}{l}\beta \text {-Human } \\
\text { chorionic } \\
\text { gonadotrophin }\end{array}$ \\
\hline
\end{tabular}

$\begin{array}{ll}0 & 0 \\ 0 & 0 \\ 0 & 0 \\ 0 & 0 \\ 0 & 0 \\ 0 & 0 \\ 0 & 0 \\ 0 & 0 \\ 0 & 0 \\ 1 & 0 \\ 1 & 0 \\ 2 & 0 \\ 1 & 0 \\ 1 & 0 \\ & 0 \\ 0 & 0 \\ 0 & 0 \\ & \\ 0 & 0 \\ 0 & 0 \\ 0 & 2 \\ 0 & 0\end{array}$

carcinoma of the thyroid. ${ }^{21}$ CRF activity was observed in several ectopic tumours that caused Cushing's syndrome, often in association with ACTH. ${ }^{22} 23$ Our results suggest that this bioactive CRF may be due to the presence of peptides other than authentic CRF-41, such as bombesin, which was found in seven of our cases, including one where this peptide was regarded as the causative agent of the observed Cushing's syndrome, via a potentiating effect on hypothalamic CRF-41. ${ }^{5}$

The correlation between immunocytochemical results and clinical observations was remarkably good. The patients had been divided into two groups, purely on the basis of overt or occult tumours at the time of presentation, and it is not surprising that this correlated with the nature of the tumours. Thus rapidly growing tumours with widespread metastases were found in group 1 patients, while group 2 tumours were smaller, slower growing, and less aggressive in nature. We found that cells of highly malignant tumours causing Cushing's syndrome did not contain sufficient hormone for immunocytochemical confirmation. In a similar study to ours $^{24}$ it was likewise found that neither immunoreactive ACTH nor immunoreactive $\beta$-endorphin could be shown in two of eight cases of ectopic Cushing's syndrome. Those two cases were malignant tumours, with widespread metastases present at surgery. One other case was diagnosed as malignant, and immunoreactive ACTH cells were only sparsely present. From the details given, it seems the remaining five cases in this report showed clinical and survival features in common with our group 2 patients, and positive immunostaining was found in all five cases.

One possible explanation for the negative immunocytochemical reactions in our group of six highly malignant tumours is heterogeneity of cells - that is, the areas we examined happened to be devoid of positive cells. We feel this to be unlikely, especially as we examined more than one area, including metasases, in three cases, and multiple sections were stained in all cases. A more feasible explanation for our results is that cells of these tumours rapidly secreted ACTH, with concomitant secretion of precursor fragments, leaving insufficient amounts stored that could be shown by our technique. This proposal is in keeping with the low concentration of ACTH found in extracts of malignant ectopic Cushing's tumours, ${ }^{10}$ even though these patients suffer from excessively 
high plasma ACTH. ${ }^{1}$ The paucity of other regulatory peptides seen in these tumour cells may likewise be due to rapid secretion. We therefore conclude that one feature of highly malignant endocrine tumours is an excessively high secretion rate leading to low storage concentrations of peptide hormones.

This work was supported by the Wellcome Trust (Grant No 13950/1.5). We thank members of the protein hormone and chemical endocrinology laboratories at St Bartholomew's Hospital for the gifts of antisera and the staff of the endocrinology department. Tissue from case 17 was received from Dr J G B Millar, St Mary's Hospital, Portsmouth.

\section{References}

1 Howlett TA, Drury PL, Perry L, Doniach I, Rees LH, Besser GM. Diagnosis and management of ACTH-dependent Cushing's syndrome: comparison of the features in ectopic and pituitary ACTH production. Clin Endocrinol 1986;24:699-713.

2 Eipper BA, Mains RE. Structure and biosynthesis of proadrenocorticotropin/endorphin and related peptides. Endocrinology Review 1980;1:1-27.

3 Carey RM, Varma SK, Drake CR, et al. Ectopic secretion of corticotropin-releasing factor as a cause of Cushing's syndrome. A clinical, morphologic and biochemical study. $N$ Engl J Med 1984;311:13-20.

4 Tapia RJ, Polak JM, Barbosa AJA, Bloom SR, Dermody C, Pearse AGE. Neuron-specific enolase is produced by neuroendocrine tumours. Lancet 1981;i:808-11.

5 Howlett TA, Price J, Hale AC, et al. Pituitary ACTH dependent Cushing's syndrome due to ectopic production of a bombesin like peptide by a medullary carcinoma of the thyroid. Clin Endocrinol 1985;22:91-101.

6 Brown WH. A case of pluriglandular syndrome. "Diabetes of beared women". Lancet 1928;ii:1022-3.

7 Christy NP. Adrenocorticotrophic activity in the plasma of patients with Cushing's syndrome associated with pulmonary neoplasms. Lancet 1961;i:85-6.

8 Meador CK, Liddle GW, Island DP, et al. Cause of Cushing's syndrome in patients with tumours arising from "nonendocrine" tissue. J Clin Endocrinol Metab 1962;22:693-703.

9 Azzopardi JG, Williams ED. Pathology of "non-endocrine" tumors associated with Cushing's syndrome. Cancer 1968;22:274-86.

10 Rees LH, Ratcliffe JG. Ectopic hormone production by nonendocrine tumours. Clin Endocrinol 1974;3:263-99.

11 Liddle GW, Nicholson WE, Island DP, Abe K, Lowder SC.
Clinical and laboratory studies of ectopic humoral syndromes. Recent Prog Horm Res 1969;25:283-305.

12 Saito E, Odell WD. Corticotropin/lipotropin common precursorlike material in normal rat extrapituitary tissues. Proc Natl Acad Sci USA 1983;80:3792-6.

13 Neville AM. Pathological aspects of the para-endocrine syndrome. Proceedings of the Royal Society of Medicine 1972;65:55-9.

14 Mason AMS, Ratcliffe JG, Buckle RM, Mason AS. ACTH secretion by bronchial carcinoid tumours. Clin Endocrinol 1972;1:3-25.

I5 Miura K, Demura H, Sato E, Sasano N, Shimizu N. A case of ACTH-secreting cancer of the colon. J Clin Endocrinol Metab \$ิ 1970;31:591-5.

16 Balsam A, Bernstein G, Goldman J, Sachs BA, Rifkin H. Ectopic $\vec{\odot}$ ACTH syndrome associated with carcinoma of the colon. Gastroenterology 1972;62:636-9.

17 Ratter SJ, Gillies G, Hope J, et al. Pro-opiocortin related peptides in human pituitary and ectopic ACTH secreting tumours. Clin Endocrinol 1983;18:211-8.

18 Hamid QA, Bishop AE, Sikri KL, Varndell IM, Bloom SR, Polak JM. Immunocytochemical characterization of 10 pancreatic 6 tumours, associated with the glucagonoma syndrome, using io antibodies to separate regions of the pro-glucagon molecule of and other neuroendocrine markers. Histopathology 1986;10: $119-33$.

19 Martin R, Cetin Y, Fehm HL, Fahlbusch R, Voigt KH. Multiple $\vec{c}$ cellular forms of corticotrophs in surgically removed pituitary $\mathcal{C}$ adenomas and periadenomatous tissue in Cushing's disease. Am J Pathol 1982;106:332-41.

20 Vale W, Spiess J, Rivier C, Rivier J. Characterisation of a 41 residue ovine hypothalamic peptide that stimulates secretion of $\mathbb{\Phi}$ corticotropin and $\beta$-endorphin. Science 1981;213:1394-7.

21 Belsky JL, Cuello B, Swanson LW, Simmons DM, Jarrett RM $\overrightarrow{0}$ Braza F. Cushing's syndrome due to ectopic secretion of corticotropin-releasing factor. J Clin Endocrinol Metok 1985;60:496-500.

22 Upton GV, Amatruda TT. Evidence for the presence of tumō peptides with corticotropin-releasing factor-like activity in the ectopic ACTH syndrome. $N$ Engl J Med 1971;285:419-24.

23 Yamamoto H, Hiarta Y, Matsukura S, Imura H, Nakamura M, Tanaka A. Studies on ectopic ACTH-producing tumours IV. CRF-like activity in tumour tissue. Acta Endocrinol 1976; 82: 183-92.

24 Heitz PU, Kloppel G, Polak JM, Staub JJ. Ectopic hormone production by endocrine tumours: localisation of hormones at the cellular level by immunocytochemistry. Cancer 1981: 48:2029-37.

Requests for reprints to: Mr PJ Coates, Department of Histopathology, St Bartholomew's Hospital, West Smithfield, London EClA 7BE, England. 